\title{
THE EFFECT OF NEWTONIAN DYNAMICS STEM-INTEGRATED LEARNING STRATEGY TO INCREASE SCIENTIFIC LITERACY OF SENIOR HIGH SCHOOL STUDENTS
}

\author{
Listiana $^{1}$, Abdurrahman ${ }^{* 2}$, Agus Suyatna ${ }^{3}$, Prasart Nuangchalerm ${ }^{4}$ \\ ${ }_{1,2,3}$ Physics Education Department, Faculty of Teacher Training and Education, Universitas Lampung, Indonesia \\ ${ }^{4}$ Department of Curriculum and Instruction, Faculty of Education, Mahasarakham University, Thailand \\ *Correspondence address: abdurrahman.1968@fkip.unila.ac.id
}

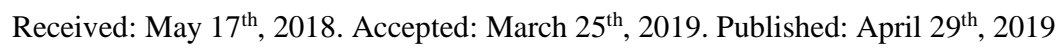

\begin{abstract}
This research aimed to examine Sains, Technology, Engineering, Mathematics (STEM) learning approach effectivity in increasing scientific literacy of senior high school students. The research involved 67Senior High School 5 students Bandar Lampung in Lampung Province, Indonesia. The research design used was the-Equivalent Control Group Pretest and Posttest Design. The experimental class used STEM Learning Approach, and the control class used a scientific approach. The data was collected using pretest and posttest score of scientific literacy inventory. The Effectiveness analysis was done using the Normalized Gain (N-Gain) and Effect Size. Based on the research, the average score of the scientific literacy skill with $N$-gain of experimental classes was 0.55 and control class was 0.49 , both classes were in medium category achievement. The result of effect size test showed that STEM learning approach has an effect size in the medium category of 0.24. Furthermore, based on an analysis of T-test results, there was a difference between the $N$-gain average score of the students' scientific literacy skill between experimental class and control class. The students who learned with STEM learning approach has a significantly higher degree of scientific literacy skill than those who learned with the scientific approach. So the conclusion in this research is that the students taught using the STEM approach are in the "conceptual" category which is better in explaining the concept, able to describe the relationship between these concepts, and able to analyze alternative solutions and procedural skills and understanding of the process of discovering science and technology.
\end{abstract}

C 2019 Physics Education, UIN Raden Intan Lampung, Indonesia

Keywords: engineering, mathematics, science, scientific literacy, technology

\section{INTRODUCTION}

The quality of science education can be seen from the results of a global assessment named PISA. PISA is an acronym for Program for International Student Assessment, which was initiated by the Organization for Economic Cooperation and Development (OECD) or the organization for economic cooperation and development, to evaluate education systems of 72 countries around the world (OECD, 2016). PISA assesses the extent to which 15-year-old students, near the end of their compulsory education, have acquired key knowledge and skills that are essential for full participation in modern societies. The assessment focuses on the core school subjects of science, reading, and mathematics (OECD, 2016).
Based on the results of the PISA study in 2015, Indonesia received ratings of 64 of the 72 participating countries. One aspect of the PISA assessment is students'scientific literacy. Related to scientific literacy, Indonesia ranked up six levels in 2015 of the last two positions in 2012. However, the general skill of scientific literacy of Indonesian students is still low. It can be seen from the average score of students'scientific literacy Indonesia which is 403 where the international average score is 493 . Indonesia ranked lower than Thailand that scored 421 and Singapore which is in the first rank with the score of 556 (OECD, 2016). This is also supported by data from interviews to two teachers of physics at Senior High School in Lampung Province of Indonesia which revealed that the level of scientific literacy of students is still 
low, this is indicated in the low-skill students in solving the problems associated with the application in daily life. The research results from (Afriana, Permanasari, \& Fitriani, 2017) reveal that many students in Indonesia are not able to relate the science knowledge they had learned with the phenomena that occur in the world, because they do not gain experience to associate it.

The causes of low scientific literacy of students in Indonesia are caused by the lack of textual and contextual learning. More teachers to transfer their knowledge to students without giving an opportunity to the students to build their own knowledge of their minds. This is relevant to the research results by (Suastra, 2005) that reveals that science learning is happening today less used in the environment surrounding the students. The students' are having difficulties to connect science concepts possessed to everyday life. The poor condition of Indonesian students' science literacy skills, if not addressed, will result in low quality of human resources and it will hamper the progress of science and technology in Indonesia.

According to the National Science Teachers Association (Honey, Pearson, \& Schweingruber, 2014), someone who has a science and technology literacy will find out how science and technology affect society.

Scientific literacy in PISA measures three components based on logic, reasoning, and critical analysis. The three components are used to find out the students' skill to identify the issues (problems) of science, explain the phenomena scientifically, and use scientific evidence (Shofiyah, 2016). Thus, when students master the scientific literacy, they will be able to understand that the modern society highly dependent on technology and progress, as well as the development of science (Kusuma Astuti, 2016).
The main problems in the study of Science (Physics), which to date have not got the solution thoroughly is the existence of a presumption to students that this lesson is difficult to grasp and understand. It is similar to the results of research carried out by (Breakspear, 2012) which suggests that the physics learning is not relevant and does not favor the students. It is caused by the absence of linkages in learning science. The emphasis of the understanding of the basic concepts and understanding of the basic science is not associated with things related to daily life, whereas Yager and Lutz further revealed that science is relevant to the process and product used in everyday society (Anghelache, 2004). One of the constraints of the other science study is due to the lack of skill to read and interpret the readings. In addition, the students' skill in logical thinking, rational, as well as systematic also low for most of the Indonesian students (Khoeruningtyas, Permanasari, \& Hamidah, 2016).

It is deemed appropriate to solve the above problems by adopting a learning approach that encourages students to build scientific literacy. One of the solutions is Sains, Technology, Engineering, Mathematics (STEM) learning approach that provides opportunities for teachers to demonstrate to students the concepts, principles, science, technology, engineering, and mathematics integrated into the development of products, processes, and systems used in their daily lives. The definition of STEM education as an interdisciplinary approach to learning is where the students use science, technology, engineering, and mathematics in real contexts that connect between school, work, and global world, thus, developing STEM literacy that enables the students to compete in the new era of knowledge-based economy (Afriana, Permanasari, \& Fitriani, 2016). 
Education in science, mathematics, engineering, and technology (STEM) is widely recognized as a pressing state and national priority (Honey et al., 2014). So far, the movement of STEM education that have been implemented in developed countries such as Japan, Korea, Australia, and the United Kingdom or of developing countries such as Thailand, Singapore, and Malaysia, looking STEM education as a solution to the problem of human resources quality and competitiveness of the nation (Rustaman, 2008). Awareness of the importance of STEM education has emerged among education experts in Indonesia. Indonesia itself has not implemented STEM education. This is supported by the results of interviews with the teachers of Senior High School in Lampung Province of Indonesia. The results of the interview stated that the learning process is not all related to technology and engineering / technical concept so that the control is not maximized.

The purpose of this study is to describe the increase of scientific literacy of senior high school students with the implementation of the STEM learning approach.

\section{METHOD}

This research was conducted at Senior High School 5 of Bandar Lampung in Lampung Province of Indonesia with purposive sampling technique. This study took a portion of the population to be sampled, one class as the experimental class and one class as the control class with the background of having the same academic skills. The experimental class implemented the STEM learning approaches, and the control class implemented the scientific approach.

The number of samples in the experiments class was 35 students and the number of samples in the control class was 32 students. This study is a Non-
Equivalent Control group pretest-posttest design.

This study consists of two research variables; the independent variable and the dependent variable. The independent variables are the STEM learning approach and the scientific approach, the variable dependent variable is scientific literacy.

This study employed ten questions to measure students' scientific literacy skills. The questions were adapted from the research by (Winata, Cacik, \& R. W, 2018) which consist of four aspects (nominal, conceptual/functional, procedural, and multidimensional). The measurement of students' scientific literacy skills was done by measuring the $\mathrm{N}$-gain obtained after pretest and posttest. The homogeneity and normality tests were also conducted. The hypothetical tests used was the independent sample ttest, Analysis of Covariant, and Effect Size test.

\section{RESULTS AND DISCUSSION}

The research was conducted on the First Grade of Senior High School in Lampung Province of Indonesia. The experimental class implemented the STEM learning approaches and the control class implemented the scientific approach (observing, questioning, associating, experimenting, and communicating).

There were four meetings for each class. Before conducting the research, the validity and reliability test was conducted on the pretest and posttest items.

Ten items of scientific literacy skills were declared valid because $t_{\text {critical }}>t_{\text {table }}$, where $t_{\text {table }}$ was 0.396 . The instrument of scientific literacy skill in the study was reliable to be used because the value of Cronbach's Alpha was 0.825 .

The average $\mathrm{N}$-gain of the scientific literacy skill in the study was reliable to be used as can be seen in Table 1. The results found out that the values are similar within the medium category. 
Table 1. The N-Gain of Students' Scientific Literacy Skill

\begin{tabular}{ccc}
\hline Acquisition of Score & Experiment Class & Control Class \\
\hline Average posttest value & 64.46 & 60.69 \\
Average pretest value & 21.03 & 23 \\
Gain Highest & 62 & 52 \\
Gain Lowest & 32 & 18 \\
Average Gain & 43.43 & 37,69 \\
Increase average Score & $43 \%$ & $38 \%$ \\
Average N-gain & 0.55 & 0.49 \\
Category & medium & medium \\
\hline
\end{tabular}

$\mathrm{N}$-gain data of experimental class and control class was normally distributed with the values of Asymp. Sig. (2-tailed) Higher than 0.050 which was 0.355 for the experimental class and 0.308 for the control class. Based on the results of these tests, it can be concluded that the data values of scientific literacy skills of the two classes were normally distributed.

Based on the homogeneity data from the results of scientific literacy skills, both classes have the same variance because the value obtained was more than 0.050 which was 0.656 , indicating that $\mathrm{H}_{0}$ is accepted and the data has a homogeneous variant.

Having obtained the normal and homogeneous distribution of data, the testing of hypotheses to answer the problem was conducted. The hypothesis test in this study was carried out using independent sample t-test, Analysis of Covariance (ANCOVA) test and Effect Size test. The hypothesis in this study are:
$\mathrm{H}_{0}$ : There is no difference in the average $\mathrm{N}$-gain between the experiment class and control class.

$\mathrm{H}_{1}$ : There is a difference in the average $\mathrm{N}$-gain between the experiment class and control class.

In table 2, there is a significant difference in the average $\mathrm{N}$-gain between the experimental class and control class. Results of the analysis of covariance are shown in Table 3. The results of these tests show that there are differences in the average $\mathrm{N}$-gain of the experimental class and control class. The effect size test result using Cohen's formula is shown in table 4. The test results indicate that the implementation of STEM learning approach on the First-Grade students of Senior High School in Lampung Province of Indonesia is in the medium category.

Table 2. The Results of Independent Sample T-Test

\begin{tabular}{cccc}
\hline Scientific Literacy & Sig. & Different & Not Different \\
\hline Cognitive & 0.78 & $\sqrt{ }$ & - \\
\hline
\end{tabular}

Table 3. The Results of ANCOVA

\begin{tabular}{ccccccc}
\hline Class & N & mean & SD & Std.error & F & Hypothesis \\
\hline Experiment & 35 & 0.55 & 0.89 & 0.52 & \multirow{2}{*}{7.07} & H$_{1}$ accepted \\
control & 32 & 0,49 & 0.10 & 0.45 & & \\
\hline
\end{tabular}

Table 4. The Results of Effect Size

\begin{tabular}{ccc}
\hline Implementation of & Effect Size $\boldsymbol{r}$ Calculation & Category \\
\hline STEM Approach & 0.24 & Medium \\
\hline
\end{tabular}


The Influence of STEM Learning Approach in Increasing Students' Scientific Literacy Skills

There is a difference in the average $\mathrm{N}$ Gain of the scientific literacy skills between the experiments class and control class.

In the experimental class, learning in the classroom is more effective to cultivate students' scientific literacy skills compared to the control class. The learning process by using the STEM approach guided students in observing, questioning, associating, experimenting, and communicating a phenomenon that occurs in daily life (Science as a process).

Then the students were given "Applications of Physics" which aims to help them understand the bike technology that is related to the concept of wheels, inertia, the second law of Newton, Third Law of Newton, the incline, the frictional forces, and the street cornering that are often encountered in daily life (Technology as Application of Science). In the next stage, the students are given an understanding of the engineering techniques procedure design. The goal is to make the students ready when dealing with the development of technology (Engineering as Engineering Science). In the final stage, the students are encouraged to model the mathematical formulas themselves that exist in the material being studied (Mathematics as a tool). This stage encourages students to perform a number of the critical-thinking processes so the impact on the achievement of learning outcomes could be satisfying. Miller proposes that scientific literacy can be defined as the skill to read and write science and technology (Miller, 1983). Further, a person's skill in science is strongly influenced by the systematic, logical, and rational way of thinking which is highly trained in mathematics. Both of these skills will be used to conduct a critical analysis of the phenomenon of science and use it when someone doing troubleshooting of context-related science. The skill to think logically and rationally is one of the aspects of mathematical literacy. Someone who possesses mathematical literacy usually will have the skill to think of the phenomenon with a logical, systematic, and critical thoughts.

This is consistent with the results by (Afriana et al., 2016) which states that STEM learning approach can generate meaningful learning for students through the integration of knowledge, concepts, and skills systematically and make students able to solve the problem. The statement was supported by the results of research by (Dare, Ellis, \& Roehrig, 2018). Muharomah which states that through the teaching of STEM, students have the literacy of science and technology that appear from reading, writing, studying, and doing experiments that can be the foundation for civic life and solve the problems faced in daily life (Ismayani, 2016). Dare et al., STEM reflects how knowledge is used outside of school; this knowledge is further contextualized or driven by some problem or issue (Dare et al., 2018). It can be seen in the learning process when the students are given a direct example of bicycle technology. Students and teachers see the concepts that can be observed from the bike. Students are enthusiastic about participating in the learning process. When given the worksheet to analyze the relations between the wheels of various types of bicycles, the students are interested in seeking its own kind of bike that is not presented in the worksheet. The students are tasked to analyze the relations of wheels. A lesson or unit that includes engineering can (1) provide a real-world context to students, (2) support students' problem-solving skills in that context, and (3) promote student communication skills and teamwork. Further, the incorporation of engineering as a context to teach science content has the potential to increase both students' learning and interest (Burrows \& 
Slater, 2015). Engineering can be a motivator as a natural way to learn how to integrate STEM concepts because realworld engineering problems are often complex and require the application of mathematics and science (Shernoff, Sinha, Bressler, \& Ginsburg, 2017).

In contrast, the poor scientific literacy skills of the control class are caused by the approach used by teachers where the students are guided in observing, questioning, associating, experimenting, and communicating only through the process of science. These stages will make the students unable to master the concept because learning is not given through the application of existing daily life technologies. This causes the students difficult to make sense of the application of the concept of the material that has been gained and how to re-engineer them. This statement is supported by research conducted by (Smarabawa, Arnyana, \& Setiawan, 2013) which states that learning is not based on the real problems of life cannot improve scientific literacy compared to the learning that is based on the application of the real problems of life. Because in the learning process, the teacher directly explains the concept of the material and do not look at any further application of the concept. In line with the research (Khoeruningtyas et al., 2016), state that learning is not related to the incident or the application of technology in everyday life is not able to improve scientific literacy significantly. In the learning process, students were not given a direct example of technical issues related to the concept of the material being studied. This causes the learning to be monotonous because students were only invited to find as much information in the student's handbook and the internet and then do the exercises within.

Based on the results of the calculation of posttest, the students' science literacy skills are still under minimum completeness criteria $(<72)$ and the average $\mathrm{N}$-gain and effect size of the experimental class and the control class both in the medium category. This shows that the implementation of STEM learning approach has not shown the expected results.

Categories in assessing students' science literacy skills by (Winata et al., 2018) consist of nominal, functional, conceptual/procedural, and multidimensional. The results of the category mapping of the students' science literacy skills can be seen in Figure 1. In the experimental class and control class, the skill to answer the scientific literacy questions both at the functional categories. It is a category where students are able to recall information from a textbook and to write basic facts but unable to justify their own opinion based on the text or image given. Students even know the concept of interdisciplinary but unable to describe the relationship between the concepts.

The results of the implementation of some aspects of the STEM approach are not yet satisfying and have not been applied in the learning process. In the learning process, the students do not participate in designing the engineering of the technology taught but was limited to analyzing the engineering of the technology. The results of the engineering analysis of bicycle technology can be seen in Figure 1 and the results of the engineering analysis and rough sloping street corner can be seen in Figure 2. 


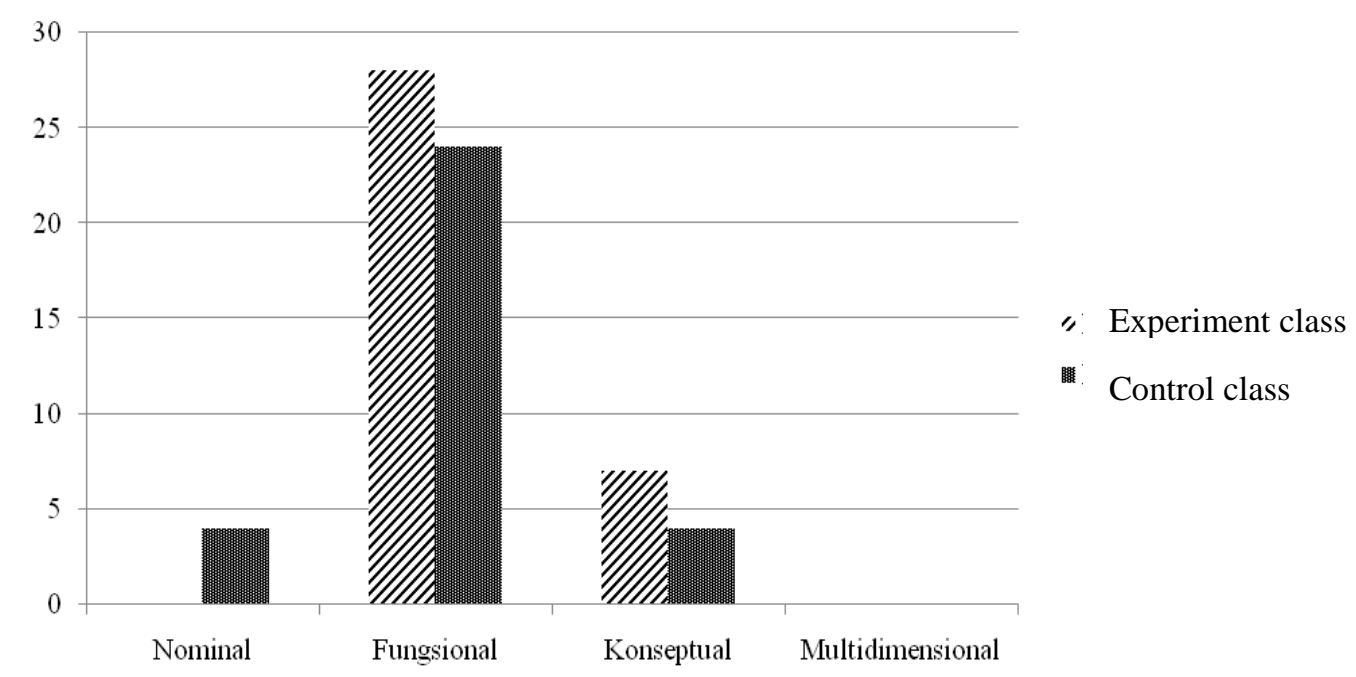

Figure 1. Students' Scientific Literacy Skills Category Mapping

On STEM learning approach, students are given a worksheet to analyze the relations of wheels of various types of bikes. At this stage, students are asked to describe the relations of engineering techniques gear, chain, and wheel in bike technology, so that students will find new ideas on how to create innovation from the principle of relations of wheels. Students model their own form of mathematical look at relations of linear speed, radius, and the angular velocity of the wheels. In addition, they should be given an understanding of the engineering techniques of bicycle technology. The students have also given the engineering problems analysis associated with the manufacturing techniques a rough road and sloping road. At this stage, students are asked to analyze engineering techniques cornering the rough/smooth surface of the road in terms of slope angles and large friction force on the road surface. Either way, it is not yet able to optimally cultivate students' science literacy skills.

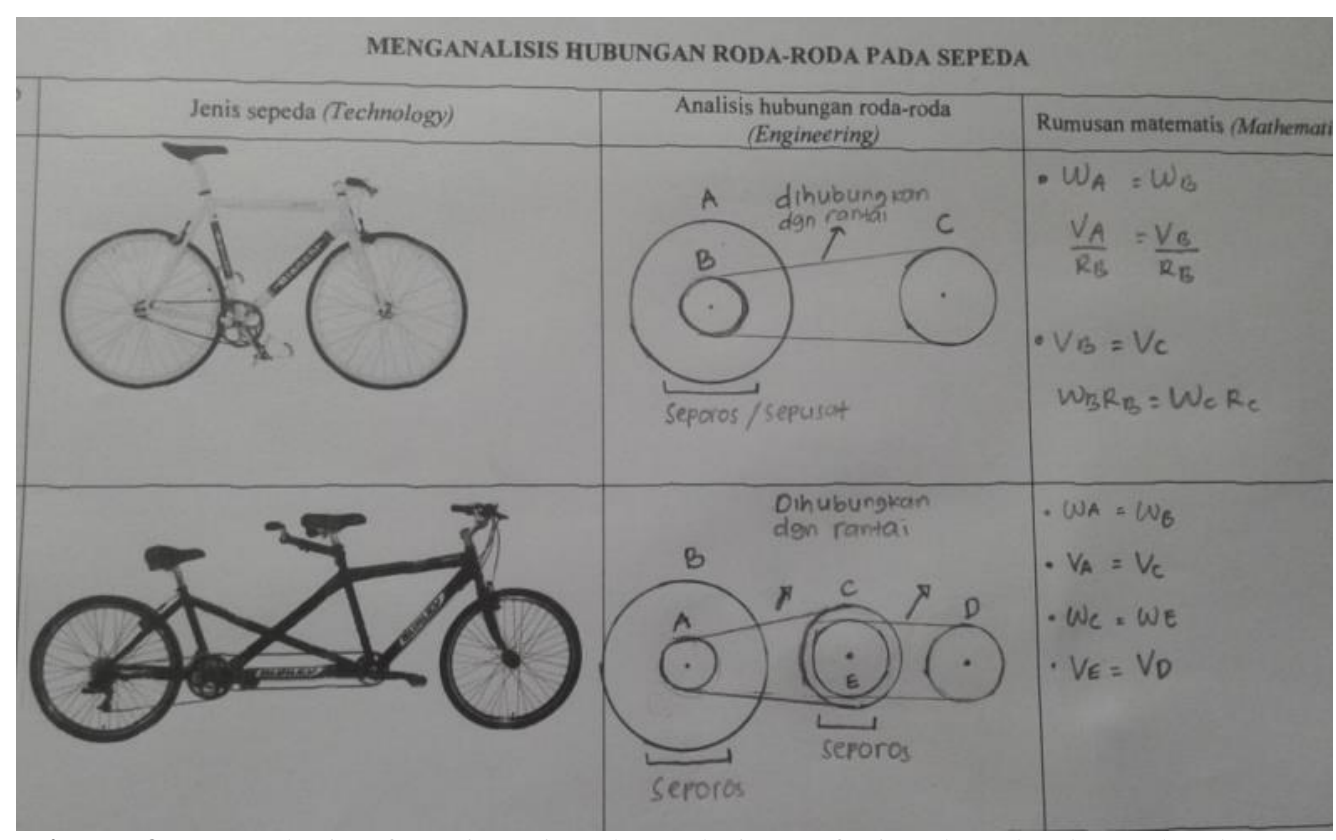

Figure 2. a. Analysis of Engineering the Relations of Bicycle Wheels Technology 


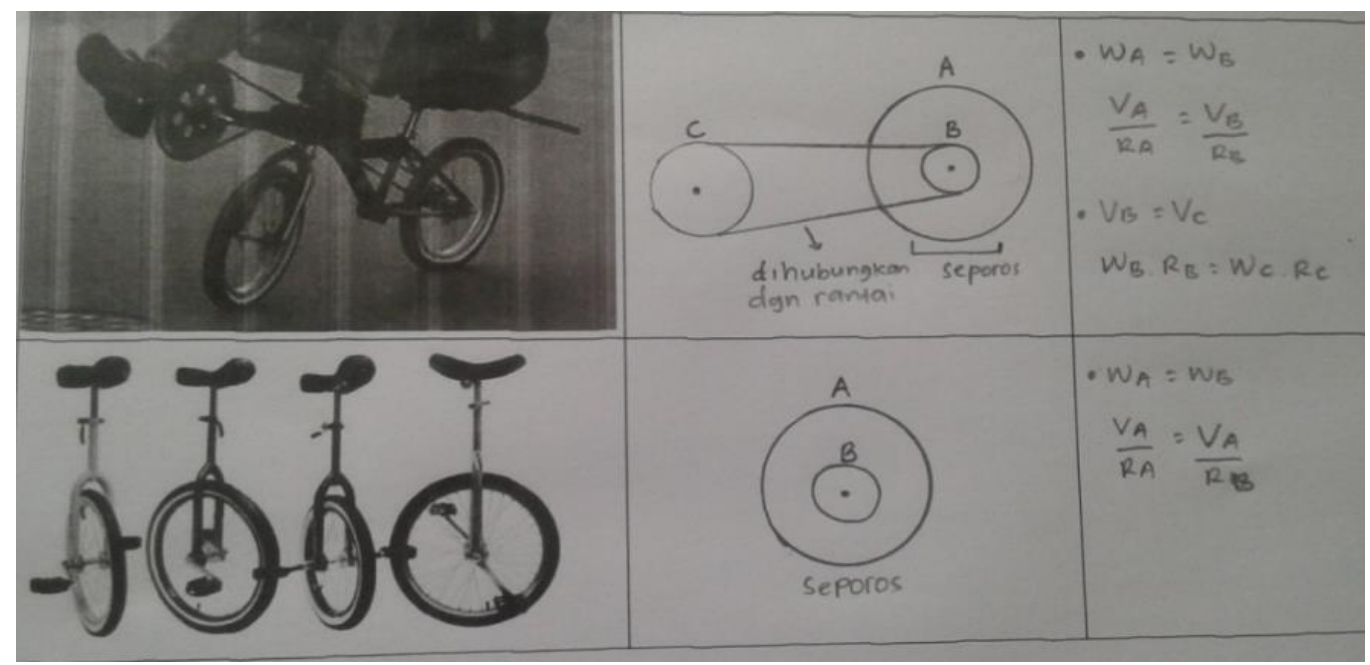

Figure 2. b. Analysis of Engineering the Relations of Bicycle Wheels Technology

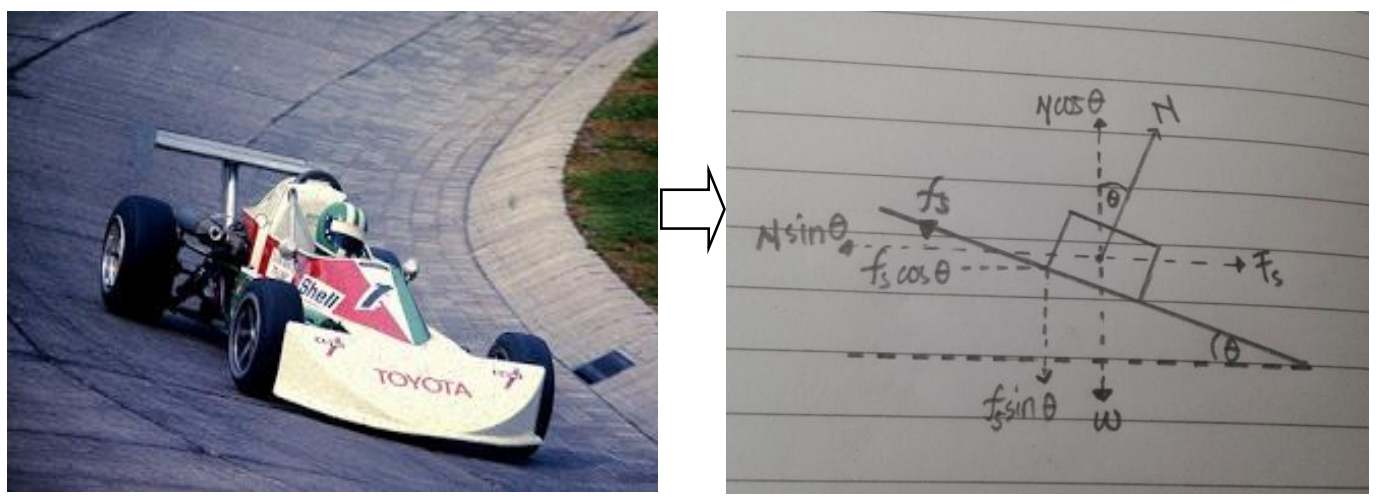

Figure 3. Analysis Engineering Sloping Curve in the Road

(Figure source: mafia.mafiaol.com)

The minimal result of students' science literacy skills toward the implementation of STEM learning approach found on the research by (Blackley, Rahmawati, Fitriani, Sheffield, \& Koul, 2018). He states that in STEM activities, the students should be encouraged to create their own visual form to the representation of the basic concepts that are focused on problem-solving or production of the product, including the application of engineering design process (e.g., expression, creation, testing, repair). Supported by research by (Suyatna, Anggraini, Agustina, \& Widyastuti, 2017), a phenomenon such as rotational motion, although easily observed in everyday life, still hard to imagine the complex relations of centripetal force or wheels. The solution to these problems is to create the visualization of the phenomenon to eliminate the abstract nature of physical phenomena. Thus, the problem of a phenomenon would be easier to solve. Integrated approaches to STEM (science, technology, engineering, and mathematics) education are increasingly popular but remain challenging and elusive. There is a hope that integrated approaches to STEM education can help the next generation of students to solve real-world problems by applying interdisciplinary concepts as well as capacities of critical-thinking, collaboration, and creativity (Burrows \& Slater, 2015). The overall results obtained provide a pretty good picture of how STEM-based learning can improve students' scientific literacy skills in a relatively short time. 


\section{CONCLUSION AND SUGGESTIONS}

\section{Conclusion}

This study found that the STEM learning approach is effective in improving students' scientific literacy skills in understanding the concepts of physics in bicycle technology and road cornering. The average $\mathrm{N}$-Gain of the scientific literacy skills of the students who were taught using the STEM approach is higher than the average $\mathrm{N}$-gain of the scientific literacy skills of the students who were taught using the scientific approach. The results are supported by the analysis of the effect size in the medium category. The STEM learning approach is well applied in the learning process because the students were given an understanding of the engineering techniques design procedure of the bicycle technology and road cornering. This process encourages students to think critically in designing technology related to daily life. The impact on the achievement of students' scientific literacy is good. In this study, the students who were taught using the STEM approach are in the "conceptual" category. They are able to explain the concept, able to describe the relationship between these concepts, and able to analyze alternative solutions and procedural skills and understanding of the process of discovering science and technology.

\section{Suggestions}

The suggestions from the results of this study are: (a) the phenomenon related to the low literacy of Indonesian students shows that there is still a need for the world of education in Indonesia to improve itself. Teachers and schools are expected to spearhead this struggle. Therefore, do change, innovation, and reform in how to teach children/train prospective teacher and students from the use of the old paradigm to become a new paradigm. STEM-based learning is one alternative learning that is potentially used to build $21^{\text {st }}$-century skills, (b) learning to use STEM approach can be used as an alternative for teachers in schools as part of efforts to improve scientific literacy skills of the students, (c) advanced researchers interested in doing further research on the implementation of STEM learning approach to students' science literacy skills in learning physics can conduct research by reviewing other technologies.

\section{REFERENCES}

Afriana, J., Permanasari, A., \& Fitriani, A. (2016). Penerapan Project Based Learning Terintegrasi STEM untuk Meningkatkan Literasi Sains Siswa Ditinjau dari Gender. Jurnal Inovasi Pendidikan IPA, 2(2), 202-212. Retrieved from http://journal.uny.ac.id/index.php/jipi Jurnal

Afriana, J., Permanasari, A., \& Fitriani, A. (2017). Penerapan project based learning terintegrasi STEM untuk meningkatkan literasi sains siswa ditinjau dari gender. Jurnal Inovasi Pendidikan IPA, 2(2), 202. https://doi.org/10.21831/jipi.v2i2.85 61

Anghelache, R. (2004). The Meaning of Scientific Literacy. International Journal of Environmental \& Science Education, 4(2), 275-288.

Blackley, S., Rahmawati, Y., Fitriani, E., Sheffield, R., \& Koul, R. (2018). Using a Makerspace approach to engage Indonesian primary students with STEM. Issues in Educational Research, 28(1), 18-42.

Breakspear, S. (2012). The Policy Impact of PISA: An Exploration of the Normative Effects of International Benchmarking in School System Performance. OECD Publishing.

Burrows, A., \& Slater, T. (2015). A Proposed Integrated STEM Framework for Contemporary 
Teacher Preparation. Teacher Education \& Practice, 28(2), 318331.

Dare, E. A., Ellis, J. A., \& Roehrig, G. H. (2018). Understanding science teachers' implementations of integrated STEM curricular units through a phenomenological multiple case study. International Journal of STEM Education, 5(1).

Honey, M., Pearson, G., \& Schweingruber, H. (2014). STEM Integration in K-12 Education: Status, Prospects, and an Agenda for Research. National Academy of Engineering.

Ismayani, A. (2016). Pengaruh Penerapan STEM Project- Based Learning Terhadap Kreativitas. Indonesian Digital Journal of Mathematics and Education, 3(4), 264-272. https://doi.org/2407-8530.

Khoeruningtyas, N., Permanasari, A., \& Hamidah, I. (2016). STEM learning in Material of Temperature and its Change to Improve Scientific Literacy of Junior High School. Jurnal Pendidikan IPA Indonesia, 5(1), 94-100. https://doi.org/10.15294/jpii.v5i1.57 97.

Kusuma Astuti, Y. (2016). Literasi Sains Dalam Pembelajaran IPA. Jurnal Unwir, 1(2).

Miller, J. . (1983). Scientific Literacy: A Conceptual and Empirical Review. Daedalus, 112(2), 29-48.

OECD. (2016). PISA 2015 Results in Focus. https://doi.org/10.1787/97892642664 90-en.

Rustaman, N. Y. (2008). Seminar Nasional VIII Pendidikan Biologi. In Seminar Nasional VIII Pendidikan Biologi, 15-34.

Shernoff, D. J., Sinha, S., Bressler, D. M., \& Ginsburg, L. (2017). Assessing Teacher Education and Professional Development Needs for the Implementation of Integrated
Approaches to STEM Education. International Journal of STEM Education, 4(1), 1-16.

Shofiyah, N. (2016). Deskripsi Literasi Sains Awal Mahasiswa Pendidikan IPA Pada Konsep IPA. Pedagogia: Jurnal Pendidikan, 4(2), 113. https://doi.org/10.21070/pedagogia.v $4 \mathrm{i} 2.13$.

Smarabawa, I., Arnyana, I., \& Setiawan, I. (2013). Pengaruh Model Pembelajaran Sains Teknologi Masyarakat Terhadap Pemahaman Konsep Biologi Dan Keterampilan Berpikir Kreatif Siswa SMA. Journal Program Pascasarjana Universitas Pendidikan Ganesha Program Studi IPA, 3.

Suastra, I. W. (2005). Merekonstruksi Sains Asli (Indigenous Science) dalam Upaya Mengembangkan Pendidikan Sains Berbasis Budaya Lokal di Sekolah. Jurnal Pendidikan Dan Pengajaran IKIP Negeri Singaraja, 1-15.

Suyatna, A., Anggraini, D., Agustina, D., \& Widyastuti, D. (2017). The Role of Visual Representation in Physics Learning: Dynamic Versus Static Visualization. In Journal of Physics: Conference Series. https://doi.org/10.1088/17426596/909/1/012048.

Winata, A., Cacik, S., \& R. W., I. S. (2018). Analisis Kemampuan Awal Literasi Sains Mahasiswa Pada Konsep IPA. Education and Human Development Journal, 1(1), 40-47. https://doi.org/10.33086/ehdj.v1i1.29 1. 